\title{
Rancang Bangun Sistem Informasi Geografis Lokasi Debitur Berbasis Web
}

\author{
Thirani Viona Therezia Mberu*1, Natalia Magdalena R. Mamulak², Paskalis Andrianus \\ $\mathrm{Nani}^{3}$ \\ ${ }^{1,2,3}$ Universitas Katolik Widya Mandira, Jl. Jendral Ahmad Yani No. 50-52, Kupang-NTT, \\ Telp.0380-833395 \\ ${ }^{3}$ Program Studi Teknik Informatika, Fakultas Teknik, UNWIRA \\ e-mail: ${ }^{1}$ bthyrani29@gmail.com, ${ }^{2}$ mamulak.natalia@gmail.com, ${ }^{3}$ paskalisnani@gmail.com
}

\begin{abstract}
Abstrak
Di dalam proses pembayaran kredit banyak terdapat masalah, diantaranya adalah pencarian lokasi debitur yang pembayarannya lambat, beberapa debitur yang lokasi tempat tinggalnya berpindah-pindah karena adanya debitur yang masih menggunakan KTP sementara. Hal ini menyebabkan karyawan dealer sulit menemukan lokasi debitur untuk melakukan penagihan kepada debitur yang bermasalah. Oleh karena itu, dibangun sebuah sistem informasi geografis yang dapat membantu karyawan dalam pencarian lokasi debitur. Tools yang digunakan dalam membangun aplikasi ini adalah bahasa pemrograman PHP 7 dan database MySQL. Dalam penelitian ini menggunakan metode pengembangan Software Development Life Cycle (SDLC) model Waterfall. Model waterfall memiliki lima tahapan yaitu analysis, design, coding, testing dan maintenance. Hasil dari penelitian ini adalah aplikasi yang dapat mendeteksi lokasi debitur yang pembayarannya melewati jangka waktu kredit (lambat) dan debitur yang pembayarannya lambat (membawa lari sepeda motor) tetapi belum melunasi pembayaran ke pihak dealer.
\end{abstract}

Kata kunci-GIS, Debitur, Kredit, NTT

\begin{abstract}
There are many problems in the process of credit payment, for example, to find out the location of the debtor who is late in the payment, debtors live nomads since they have only temporary ID Cards. This one of the reasons for the debt collectors having difficulties to find them in order to ask their payment. Therefore, it is important to build a geographic information system that can assist the employee for searching the debtor location. The tools for building this application are using PHP 7 programming language and MySQL database. This study is also using an expanding method of Software Development Life Cycle (SDLC) waterfall model. There are five stages of waterfall model i.e. analysis, design, coding, testing, and maintenance. The result provides an application for detecting the location of the debtors who are late on payment.
\end{abstract}

Keywords - GIS, Debt, Credit, NTT

\section{PENDAHULUAN}

PT. XYZ yang didirikan pada tahun 2007 merupakan salah satu dealer yang berada di Kabupaten Sumba Timur Provinsi Nusa Tenggara Timur (NTT) jasa kredit khusus motor Honda dan menawarkan pilihan jangka waktu kredit selama 16 bulan, 25 bulan, 28 bulan dan 34 bulan 
dengan uang muka yang berbeda-beda tergantung pada type motor yang dibeli. Kelengkapan dokumen sebagai persyaratan kredit adalah Fotocopy Kartu Tanda Penduduk (KTP), Fotocopy Kartu Keluarga (KK), Fotocopy Slip Gaji (khusus Pegawai Negeri Sipil/Pegawai Swasta). Calon debitur diwajibkan melengkapi fotocopy KTP dan fotocopy KK penjamin yang akan menjadi jaminan jika debitur bermasalah, penjamin ini dipastikan mempunyai lokasi tempat tinggal yang tetap.

Berikut adalah grafik volume penjualan dan grafik volume kredit pada PT. XYZ:

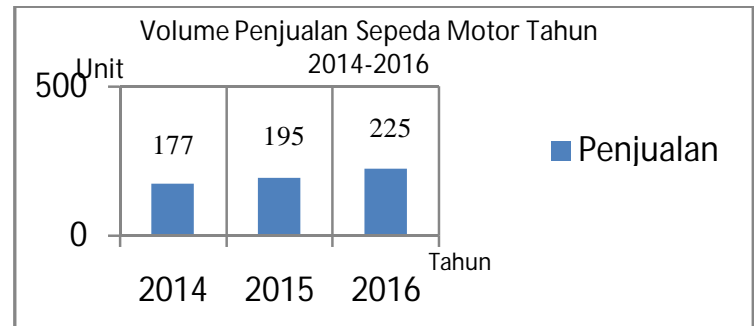

Gambar 1. Grafik Volume Penjualan Sepeda Motor

Grafik diatas menunjukkan volume penjualan sepeda motor pada PT. XYZ dari tahun 2014 sampai tahun 2016. Setiap tahunnya volume penjualan meningkat, seperti pada tahun 2014 terdapat 177 unit motor yang terjual, tahun 2015 sebanyak 195 unit motor dan pada tahun 2016 sebanyak 225 unit motor. Jumlah keseluruhan sepeda motor yang terjual dari tahun 2014 sampai pada tahun 2016 sebanyak 597 unit sepeda motor.

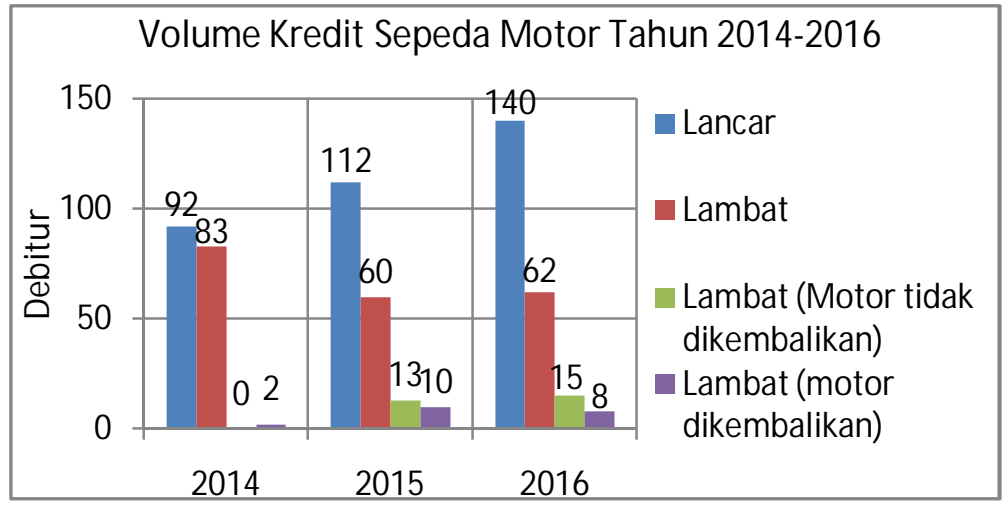

Gambar 2. Grafik Volume Kredit Sepeda Motor

Grafik diatas menunjukkan volume kredit pada PT. XYZ. Pembelian sepeda motor dengan cara kredit maupun tunai, tetapi dalam hal ini data yang ditampilkan hanya khusus pada data pembelian sepeda motor secara kredit. Dari grafik diatas bisa dilihat dari tahun 2014 terdapat 92 debitur yang pembayarannya lancar, 83 debitur yang pembayarannya lambat, 0 debitur yang pembayarannya lambat (sepeda motor tidak dikembalikan) dan 2 debitur yang pembayarannya lambat (sepeda motor dikembalikan), sedangkan pada tahun 2015 terdapat 112 debitur yang pembayarannya lancar, 60 debitur yang pembayarannya lambat, 13 debitur yang pembayarannya lambat (sepeda motor tidak dikembalikan) dan 10 debitur yang pembayarannya lambat (sepeda motor dikembalikan) dan pada tahun 2016 terdapat 140 debitur yang pembayarannya lancar, 62 debitur yang pembayarannya lambat, 15 debitur yang pembayarannya lambat (sepeda motor tidak dikembalikan) dan 8 debitur yang pembayarannya lambat (sepeda motor dikembalikan).

Masalah yang sering terjadi di dalam proses kredit adalah pencarian lokasi debitur yang pembayarannya melewati jangka waktu kredit (lambat), debitur yang pembayarannya lambat 
(membawa lari sepeda motor) tetapi belum melunasi pembayaran ke pihak dealer. Beberapa debitur yang lokasi tempat tinggalnya tidak tetap karena masih menggunakan KTP sementara. Hal ini menyebabkan kesulitan dalam menemukan lokasi debitur untuk melakukan penagihan kepada debitur yang bermasalah. Untuk menyelesaikan masalah diatas perlu dibangun sebuah Sistem Informasi Geografis yang dapat membantu mencari lokasi debitur yang bermasalah dalam proses pembayaran.

Sistem yang akan dikembangkan ini harapannya mampu mendeteksi lokasi debitur yang pembayarannya melewati jangka waktu kredit (lambat) dan debitur yang pembayarannya lambat (membawa lari sepeda motor) tetapi belum melunasi pembayaran ke pihak dealer. Sistem ini juga dapat mempermudah karyawan PT. XYZ untuk mencari lokasi tempat tinggal debitur yang bermasalah dalam proses pembayaran. Di dalam sistem ini akan dibuat sebuah warning kredit, berupa sebuah pemberitahuan kepada pihak dealer 2 minggu sebelum waktu debitur melakukan pembayaran kepada pihak dealer. Dengan adanya sistem ini, masyarakat Kabupaten Sumba Timur juga dapat mengirim pesan berupa pertanyaan atau saran serta dapat melihat informasi berupa berita terbaru tentang kendaraan bermotor, profil PT. XYZ, syarat-syarat kredit, informasi kendaraan berupa jenis, type, warna dan harga kendaraan.

\section{METODE PENELITIAN}

Penelitian sebelumnya telah banyak dilakukan diantaranya oleh Wirasandy T, et.al (2012), telah berhasil membangun sebuah aplikasi yang dapat menampilkan informasi peta persebaran nasabah menurut jumlah nasabah pada kecamatan tertentu sehingga dapat memberikan informasi data nasabah kepada Accounting Officer dalam mencari nasabah baru, menampilkan peta persebaran nasabah yang potensial untuk program BPR lain seperti kredit, tabungan dan deposito sehingga membantu Accounting Officer dalam memelihara nasabah lama agar tetap menjadi nasabah BPR Restu Klepu Makmur. [1]

Penelitian lain dilakukan oleh Zain. I, et.al (2012) mengenai Sistem Informasi Geografis Jaringan Trafo Dan Pelanggan Studi Kasus PT PLN (Persero) Rayon Rumbai menggunakan metode Waterfall telah menghasilkan informasi nama-nama pelanggan yang dialiri trafo yang sama secara tepat dan akurat dengan cara memasukkan kata kunci berupa nama trafo, menampilkan informasi dalam bentuk peta tematik sehingga pengguna dapat melihat posisi trafo serta pelanggan PLN dengan jelas, adanya informasi jarak tempuh lokasi pelanggan dari kantor PLN cabang PLN Rayon Rumbai yang disajikan dalam sistem ini mempermudah petugas menuju lokasi pelanggan jika terjadi suatu gangguan yang memerlukan tindakan segera. [2]

Penelitian lain dilakukan oleh Mamulak (2014) mengenai Sistem informasi Geografis Sebaran Tutupan Lahan Pemukiman Penduduk di Kota dan Kabupaten Kupang menggunakan pengembangan Cloud Fusion Tables telah menghasilkan sebuah peta tematik informasi pemukiman di Kota dan Kabupaten Kupang dengan menampilkan rute dan penunjuk jalan.[3]

Penelitian lain juga dilakukan oleh Mamulak, et.al (2015) mengenai Desain dan Implementasi Sistem Informasi Geografis Pariwisata di Kabupaten Timor Tengah Selatan (TTS) mengahsilkan sebuah sistem informasi geografis yang memudahkan pengunjung untuk mengetahui lokasi objek wisata dan fasilitas umum di sekitar objek wisata serta dilengkapi dengan grafik objek wisata yang paling banyak dikunjungi.[4]

Penelitian ini melengkapi penelitian yang telah dilakukan oleh Mamulak (2015) dengan memberikan informasi peta digital lokasi debitur dan penjamin serta warning pembayaran kredit bagi debitur.

Sistem informasi geografis (SIG) atau Geographic Information System (GIS) adalah sebuah sistem yang didesain untuk menangkap, menyimpan, memanipulasi, menganalisa, mengatur dan menampilkan seluruh jenis data geografis. [5] 
Web GIS adalah sejenis sistem informasi yang terdistribusi. Web GIS adalah sebuah GIS yang menggunakan teknologi Web. Dalam definisi yang lebih sempit Web GIS adalah sebuah GIS yang menggunakan teknologi web untuk berkomunikasi antara komponennya. [6]

Debitur adalah orang atau lembaga yang berutang kepada orang atau lembaga lain. Kredit adalah cara menjual barang dengan pembayaran secara tidak tunai atau pembayaran ditangguhkan atau diangsur. [7]

Google Maps merupakan salah satu fasilitas dari Google yang menyediakan layanan pemetaan suatu daerah. Pemetaan tersebut dilengkapi dengan berbagai kemampuan dan mudah digunakan. Kelengkapan lain pendukung peta tersebut seperti layanan informasi bisnis, jasa, layanan publik, jalan, lokasi dan lain-lain. [8]

Hypertext Preprocessor (PHP) merupakan mesin di belakang jutaan aplikasi web dinamis. $P H P$ memiliki fitur yang luas, pendekatan sintaks, mendukung sistem operasi dan webserver yang berbeda yang membuat $P H P$ menjadi bahasa pemrograman yang ideal untuk pengembangan web secara cepat dalam sistem yang kompleks. [9]

Metodologi penelitian yang digunakan adalah metode pengembangan Software Development Life Cycle (SDLC) model Waterfall.

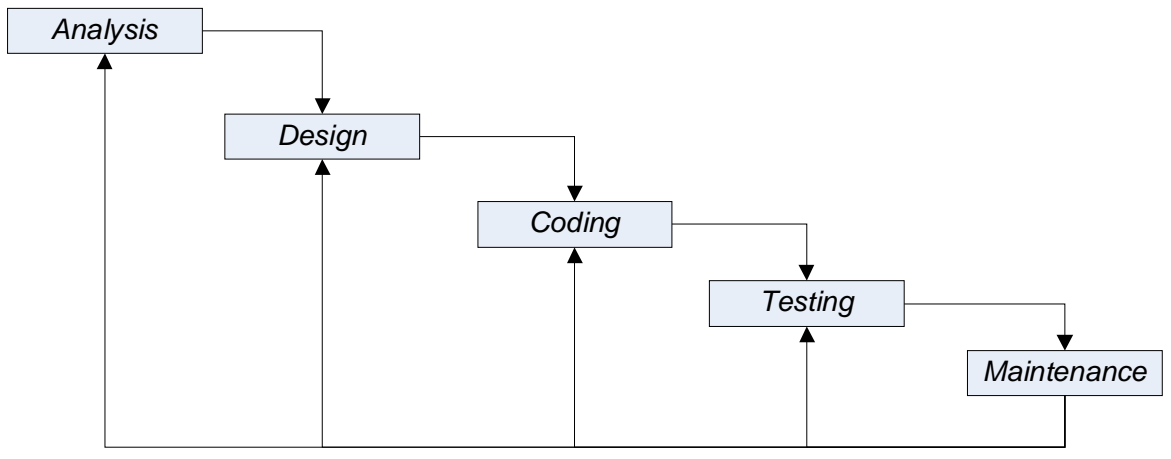

Gambar 3. Model Waterfall (Pressman, 2010)

\section{Analisis}

1. Analisis Kebutuhan Sistem

Analisis kebutuhan dilakukan untuk menentukan, memperbaiki, memodelkan, menspesifikasikan dan mengetahui fasilitas-fasilitas yang harus disediakan atau dimiliki oleh sistem untuk dapat melayani kebutuhan pengguna sistem.Fungsi utama dari sistem informasi geografis yang dibangun adalah memberikan informasi lokasi debitur yang dapat diakses atau diperlukan oleh user. Pada tahap ini akan dilakukan identifikasi mengenai informasi-informasi debitur yang diperlukan.

2. Analisis Peran Sistem

Fungsi analisis peran sistem adalah menghasilkan informasi yang berkualitas dan akurat. Informasi yang dihasilkan berkualitas dan akurat apabila terdapat fungsifungsi yang nantinya harus dimiliki oleh sistem yaitu:

a. Sistem yang dibangun meng-input data pengguna, data syarat kredit, data stok kendaraan, data penjamin, data debitur, data penjualan, data angsuran kredit, data berita, data profil dan data pesan masuk.

b. Sistem yang dibangun menghasilkan output berupa informasi lokasi debitur, lokasi penjamin, laporan penjualan dan laporan angsuran kredit per hari, per bulan dan per tahun.

3. Analisis Peran Pengguna Sistem

Pembuatan Sistem Informasi Geografis Lokasi Debitur pada PT. XYZ di Kabupaten Sumba Timur Berbasis Web memiliki beberapa tipe pengguna antara lain: 
a. Admin

Admin memiliki peran penting sebagai pengontrol isi dari website. Admin juga berperan penting untuk meng-input, menambah, mengedit dan menghapus data pengguna, data syarat kredit, data stok kendaraan, data penjamin, data debitur, data penjualan, data angsuran kredit, data berita, data profil dan data pesan masuk.

b. Karyawan

Karyawan pada bagian penagihan, yang menggunakan sistem ini untuk melakukan pencarian (search) lokasi debitur dan lokasi penjamin agar dapat melihat data lokasi debitur dan data lokasi penjamin, tetapi dibatasi hak aksesnya sehingga user tidak dapat melakukan semua hal seperti yang bisa dilakukan oleh admin.

c. Pengunjung

Pengunjung hanya sebatas melihat informasi yang di-upload oleh admin. Pengunjung juga dapat mengirim pesan berupa pertanyaan atau saran serta dapat melihat informasi berupa berita terbaru tentang kendaraan bermotor, profil PT. XYZ, syarat-syarat kredit, informasi kendaraan berupa jenis, type, warna dan harga kendaraan.

\section{Desain}

1. Flowchart Sistem

Diagram yang menunjukkan aliran data berupa formulir ataupun keterangan berupa dokumentasi yang mengalir dalam suatu sistem. Flowchart sistem ini dapat dilihat pada gambar dibawah ini:

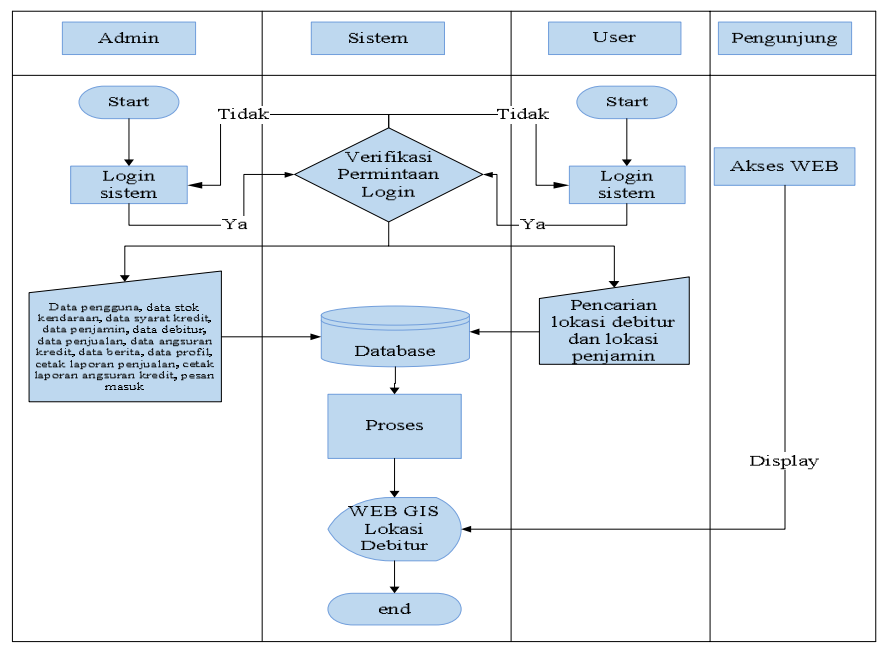

Gambar 4. Flowchart Sistem

Pada flowchart sistem di atas, admin dan karyawan harus melakukan login terlebih dahulu dengan memasukkan username dan password. Kemudian sistem akan memverifikasi permintaan login, jika username dan password sesuai maka admin dan karyawan akan masuk ke sistem dan melakukan pengolahan data. Setelah data diolah selanjutnya sistem akan memproses semua data tersebut, kemudian terorganisir dan tersimpan dalam database lalu menghasilkan output berupa informasi lokasi debitur, lokasi penjamin, laporan penjualan dan laporan angsuran kredit per hari, per bulan, per tahun melalui website. 
Setelah informasi sudah tersedia di website, pengunjung dapat mengirim pesan berupa pertanyaan atau saran serta dapat melihat informasi berupa berita terbaru tentang kendaraan bermotor, profil PT. XYZ, syarat-syarat kredit, informasi kendaraan berupa jenis, type, warna dan harga kendaraan.

\section{Diagram Konteks (Context Diagram)}

Diagram konteks merupakan diagram level tertinggi dari DFD yang menggambarkan hubungan sistem dengan lingkungan luarnya. Diagram konteks digunakan untuk menunjukkan secara garis besar hubungan dari input, proses dan output, dimana di bagian input menunjukkan item-item data yang akan digunakan oleh bagian proses. Bagian proses berisi langkah-langkah yang menggambarkan kerja dari fungsi atau modul. Sedangkan bagian output berisi hasil dari pemrosesan data.

Diagram konteksdari sistem ini seperti yang ditunjukkan pada gambar berikut ini:

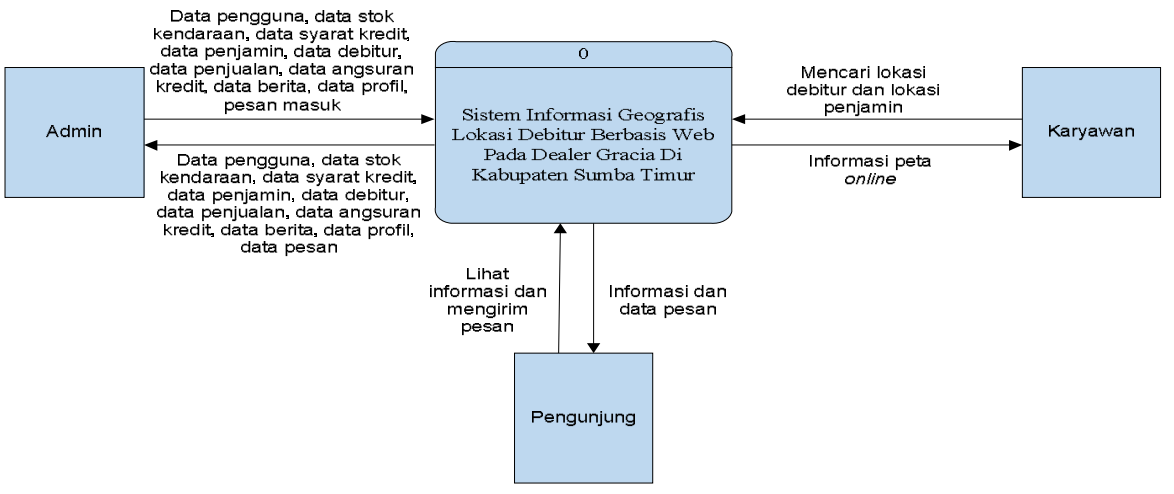

Gambar 5. Diagram Konteks

Gambar diagram konteks di atas menunjukkan bahwa admin meng-inputdata pengguna, data stok kendaraan, data syarat kredit, data penjamin, data debitur, data penjualan, data angsuran kredit, data berita, data profil dan melihat pesan masuk. Karyawan dealer mencari lokasi debitur dan lokasi penjamin. Sedangkan pengunjung dapat mengirim pesan berupa pertanyaan atau saran serta dapat melihat informasi berupa berita terbaru tentang kendaraan bermotor, profil PT. XYZ, syaratsyarat kredit, informasi kendaraan berupa jenis, type, warna dan harga kendaraan. Pengunjung akan menerima jawaban pesan dan informasi dari sistem. Semua data yang di inputakan masuk ke dalam database sistem penyebaran informasi.

3. Entity Relationship Diagram 


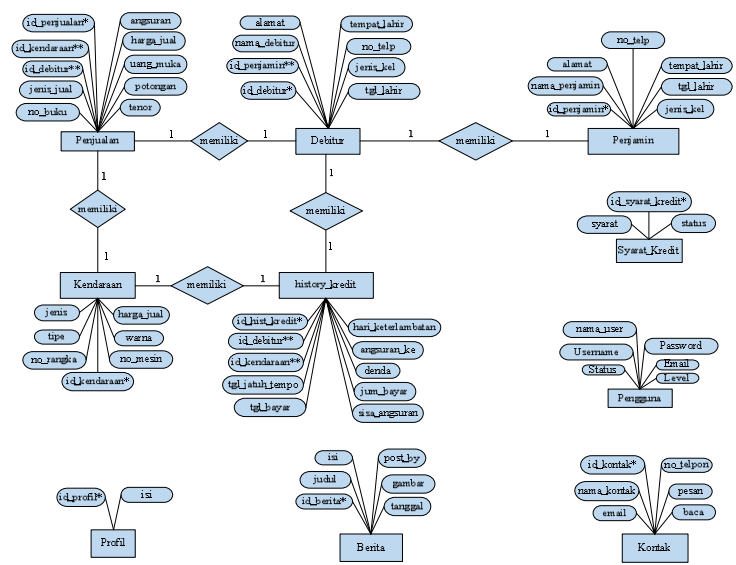

Gambar 6. E-R Diagram

4. Relasi Antar Tabel

Untuk memudahkan penyimpanan data, maka data akan disimpan dalamtabel basis data. Dari $E-R$ diagram yang merupakan hasil pemodelan sistem dapat dirancang tabel seperti pada gambar di bawah ini:

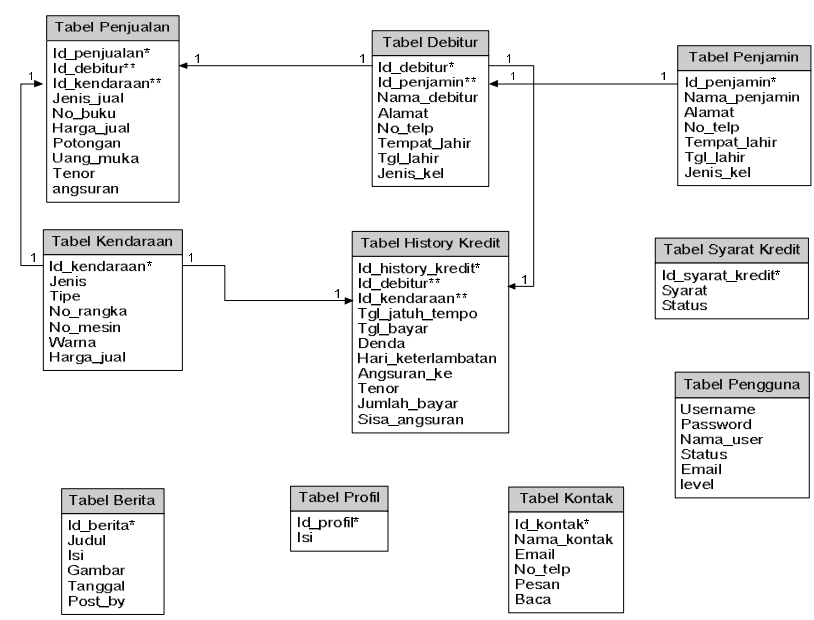

Gambar 7. Relasi Tabel

\section{HASIL DAN PEMBAHASAN}

Implementasi Sistem Informasi Geografis Lokasi Debitur Berbasis Web Di PT. XYZ Kabupaten Sumba Timur yang telah dibangun antara lain:

1. Tampilan Halaman Home

Halaman home berisi berita, kategori kendaraan dan statistik pengunjung website 


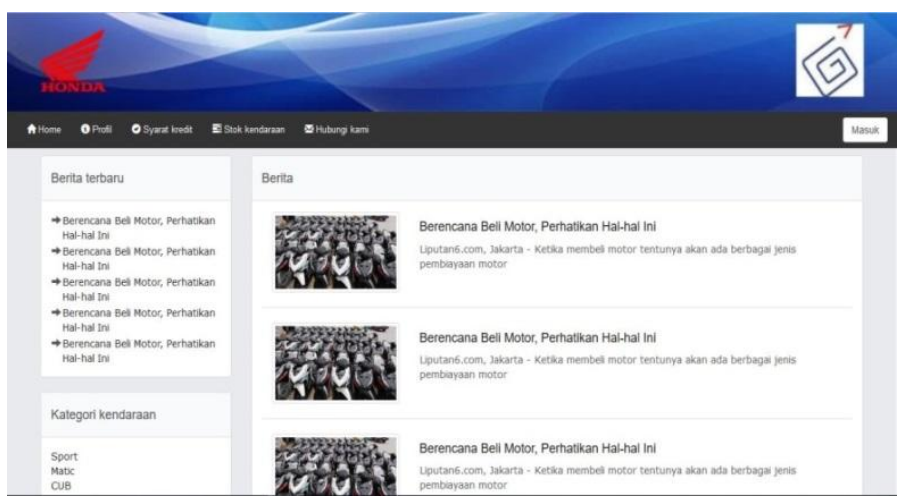

Gambar 8.Tampilan Halaman Home

2. Tampilan Halaman Profil

Halaman profil berisikan gambar peta Sumba Timur dan lokasi debitur

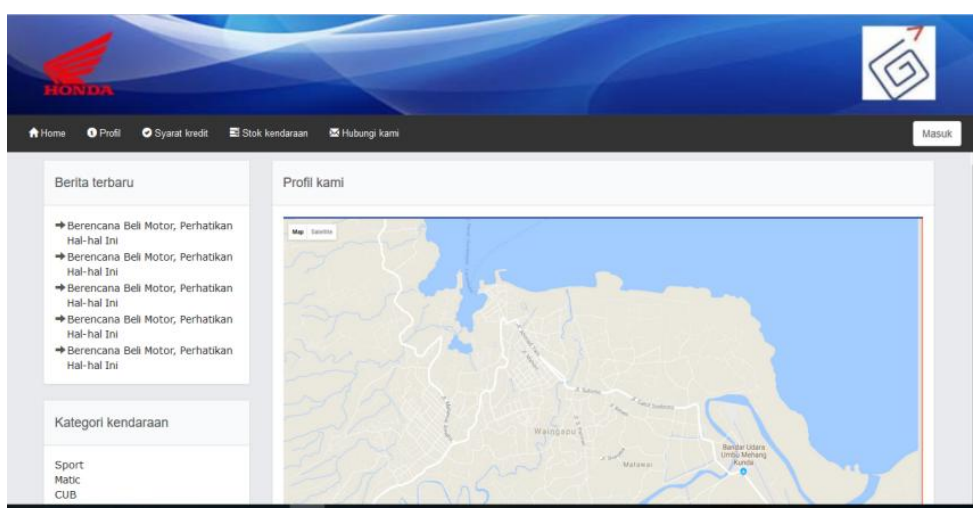

Gambar 9. Tampilan Halaman Profil

3. Tampilan Halaman Syarat Kredit

Halaman syarat kredit berisikan informasi tentang syarat-syarat kredit bagi calon debitur yang ingin melakukan kredit di PT. XYZ
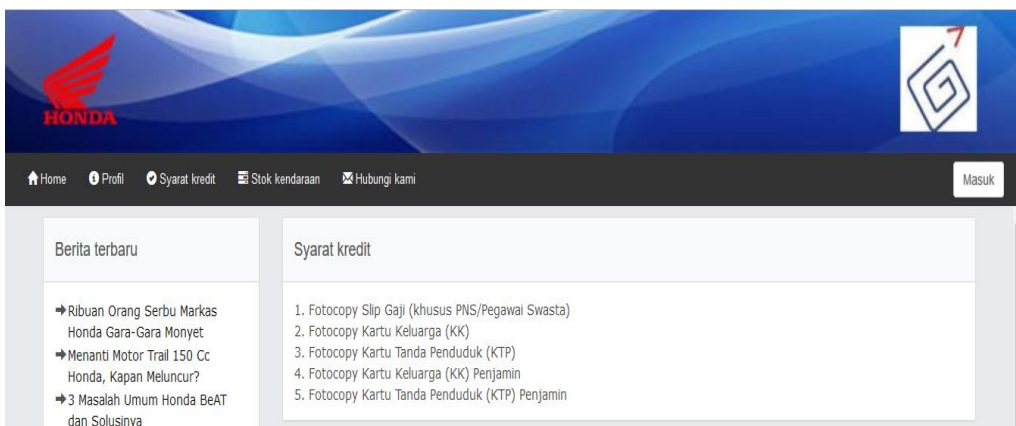

Gambar 10. Tampilan Halaman Syarat Kredit

4. Tampilan Halaman Stok Kendaraan

Halaman stok kendaraan berisikan informasi tentang jenis kendaraan, type, warna dan harga kendaraan. 

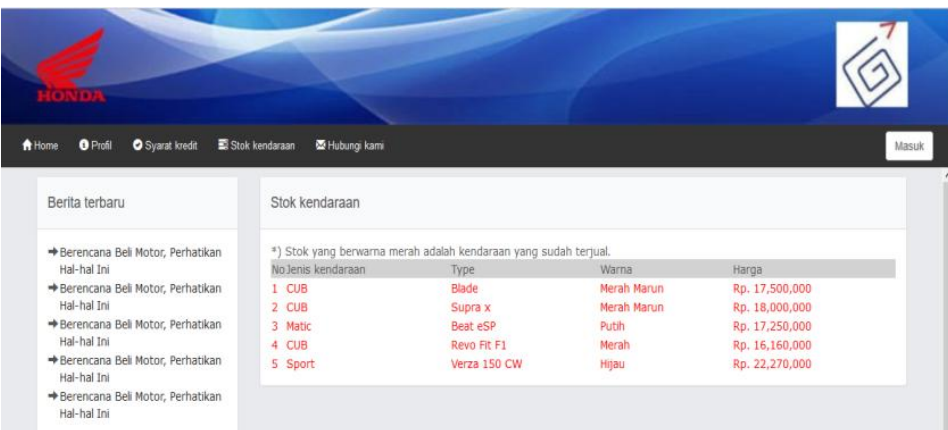

Gambar 11. Tampilan Halaman Stok Kendaraan

5. Tampilan Halaman Menu Pengunjung

Halaman menu pengunjung menampilkan beberapa sub menu diantaranya adalah sub menu berita, sub menu profil dan sub menu pesan masuk

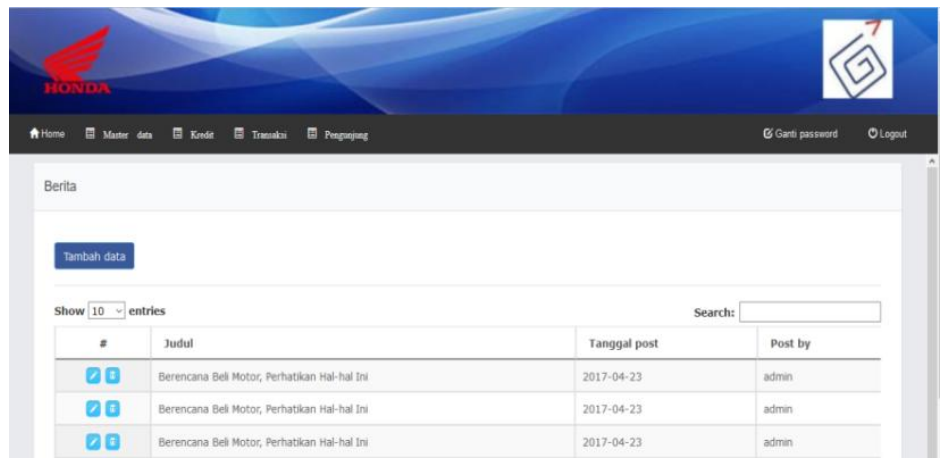

Gambar 12. Tampilan Halaman Sub Menu Berita

6. Tampilan Halaman Sub Menu Profil

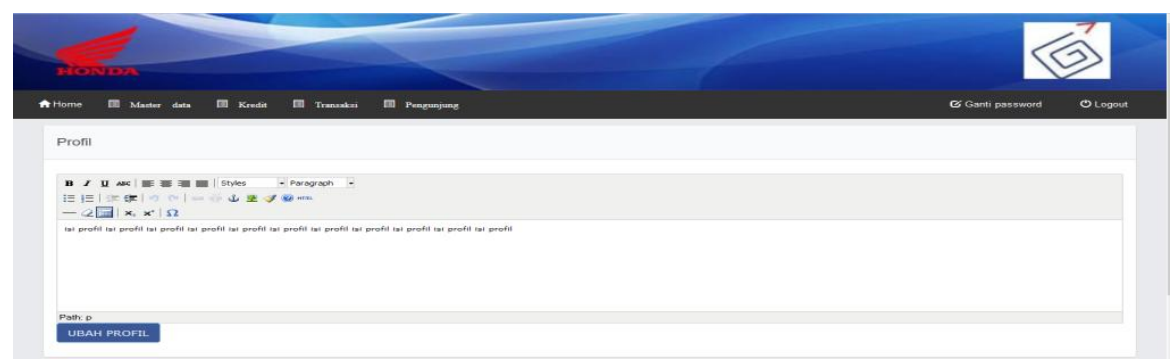

Gambar 13. Tampilan Halaman Sub Menu Profil

7. Tampilan Halaman Sub Menu Pesan Masuk

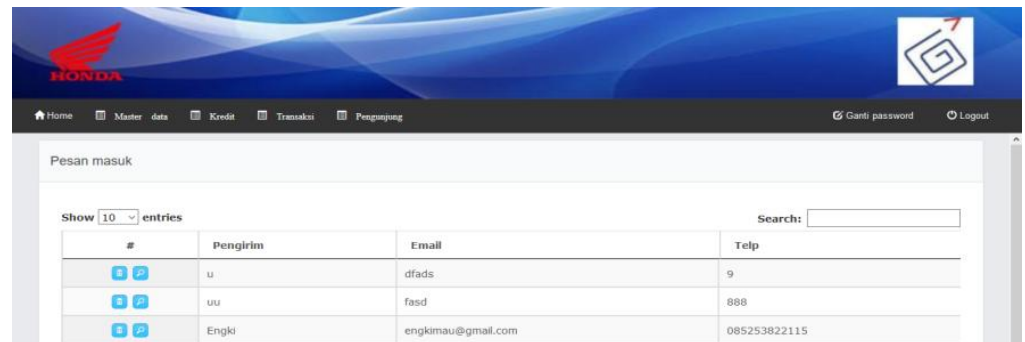

Gambar 14. Tampilan Halaman Sub Menu Pesan Masuk 
8. Tampilan Halaman Menu Karyawan

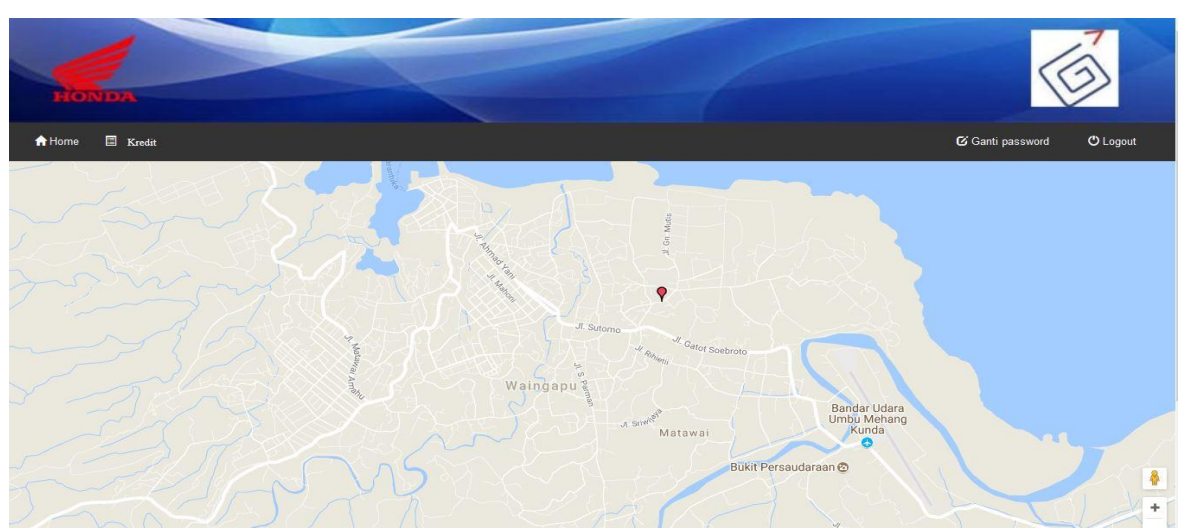

Gambar 15. Tampilan Halaman Menu Karyawan

9. Tampilan Halaman Menu Kredit
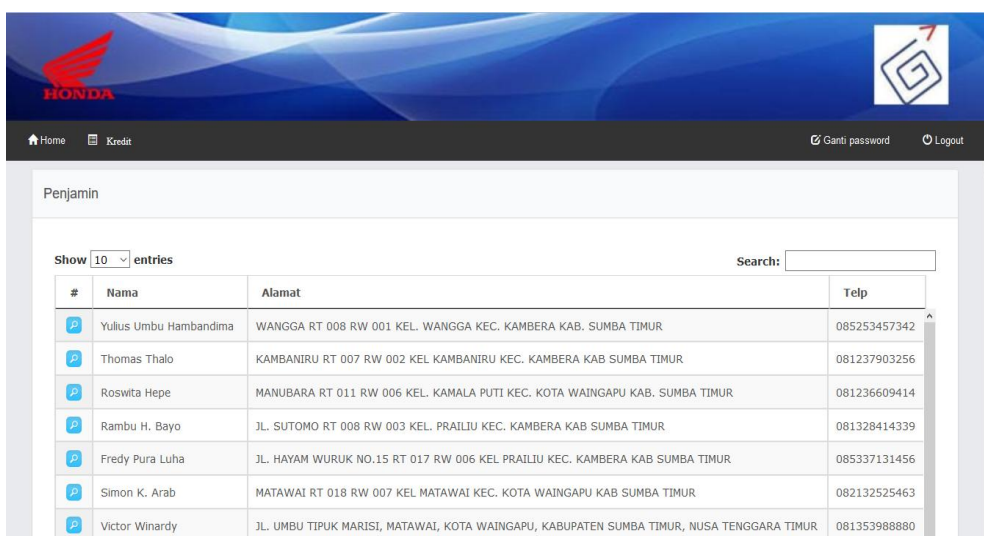

Gambar 16. Tampilan Halaman Sub Menu Penjamin

10. Tampilan Halaman Sub Menu Debitur

Pada sub menu debitur menampilkan nama debitur, alamat dan nama penjamin.

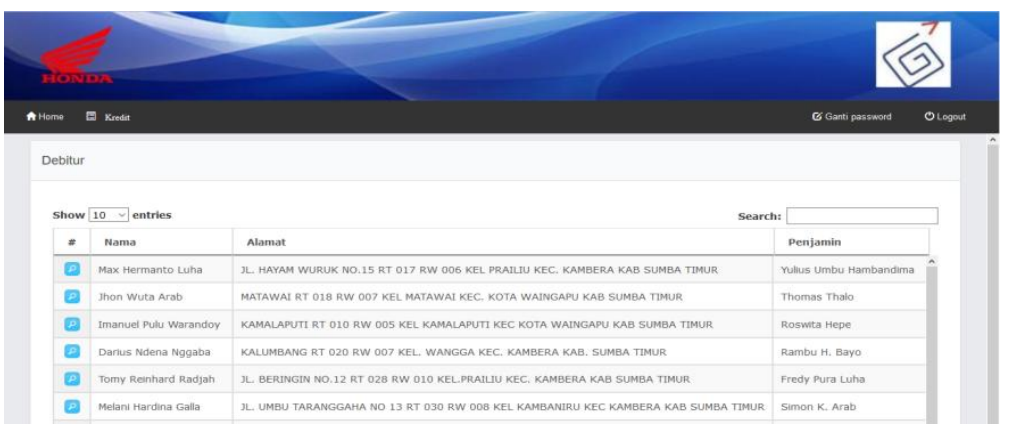

Gambar 17. Tampilan Halaman Sub Menu Debitur 


\section{KESIMPULAN} bahwa:

Berdasarkan hasil implementasi dan pengujian yang dilakukan, dapat disimpulkan

1. Dengan dibangunnya aplikasi Sistem Informasi Geografis Lokasi Debitur Berbasis Web dapat membantu karyawan bagian penagihan untuk mendapatkan lokasi debitur yang pembayarannya melewati jangka waktu kredit (lambat) dan debitur yang pembayarannya lambat (membawa lari sepeda motor) tetapi belum melunasi pembayaran ke pihak dealer.

2. Dengan adanya aplikasi ini membantu pihak dealer dalam merekap data penjualan setiap bulannya.

3. Sistem yang dibangun ini dapat diakses oleh masyarakat Kabupaten Sumba Timur untuk mengirim pesan berupa pertanyaan atau saran serta dapat melihat informasi tentang kendaraan bermotor berupa jenis, type, warna, harga kendaraan, berita terbaru tentang kendaraan bermotor, profil dealer Gracia dan syarat-syarat kredit.

\section{SARAN}

Saran-saran untuk untuk penelitian lebih lanjut untuk menutup kekurangan penelitian. Tidak memuat saran-saran diluar untuk penelitian lanjut.

Oleh karena keterbatasan kemampuan dan waktu dalam pembangunan sistem ini, sehingga tidak menampilkan informasi perhitungan atau simulasi kredit bagi calon debitur.

\section{UCAPAN TERIMA KASIH}

Penulis mengucapkan terima kasih kepada Pemerintah Kabupaten Sumba Timur, PT. XYZ dan Univeristas Katolik Widya Mandira yang telah memberikan dukungan terhadap penelitian ini.

\section{DAFTAR PUSTAKA}

[1] Wirasandy, T., Papilaya F. S., Fibriani C., 2012, Persebaran Nasabah Bank Perkreditan Rakyat (BPR) Restu Klepu Makmur dengan Menggunakan Sistem Informasi Geografis

[2] Zain, I., Sari, P. S., Fitrisia Y, 2012, Sistem Informasi Geografis Jaringan Trafo Dan Pelanggan Studi Kasus PT PLN (Persero) APJ Semarang Rayon Rumbai, Program Studi Sistem Informasi Caltex Riau, Pekanbaru

[3] Mamulak, N.M.R., 2014, Sistem Informasi Geografis Sebaran Tutupan Lahan Pemukiman Penduduk Di Kota dan Kabupaten Kupang, Proceeding Seminar Nasional Inovasi dan Tren (SNIT), pp: 458-461, ISBN: 978-602-99213-7-3, Bina Sarana Informatika, Jakarta

[4] Mamulak,N.M.R., Fallo, A.R., 2015, Desain Dan Implementasi Sistem Informasi Geografis Pariwisata Di Kabupaten Timor Tengah Selatan (TTS). Proceeding Seminar Nasional Riset Inovatif III (SENARI), pp: 386-393, ISBN: 978-602-1213-90-2, Lembaga Penelitian Universitas Pendidikan Ganesha, Denpasar 
[5] Irwansyah, E., 2013, Sistem Informasi Geografis:Prinsip Dasar dan Pengembangan Aplikasi. Digibook, Yogyakarta

[6] Fu P, Sun J., 2011, Web GIS : Principles and Applications. Ed ke-1. California (US): ESRI,

[7] Kamus Besar Bahasa Indonesia (KBBI)

[8] Febrian, J., 2008, Menjelajah Dunia dengan Google, Mesin Pencarian Informasi di Internet Terbesar di Dunia,Informatika, Bandung

[9] Skalar, D. Trachetenberg, A., 2015, PHP Cookbook: Solutions \& Examples For PHP Programmers, O'Reilly Media, Inc 